\title{
Erratum: Detailed Multiplex Analysis of SARS-CoV-2 Specific Antibodies in COVID-19 Disease
}

OPEN ACCESS

Approved by: Frontiers Editorial Office, Frontiers Media SA, Switzerland

*Correspondence: Frontiers Production Office production.office@frontiersin.org

Specialty section:

This article was submitted to

Viral Immunology, a section of the journal

Frontiers in Immunology

Received: 30 June 2021 Accepted: 30 June 2021 Published: 12 July 2021

Citation: Frontiers Production Office (2021)

Erratum: Detailed Multiplex Analysis of SARS-CoV-2 Specific Antibodies in COVID-19 Disease.

Front. Immunol. 12:733897. doi: 10.3389/fimmu.2021.733897
Frontiers Production Office ${ }^{*}$

Frontiers Media SA, Lausanne, Switzerland

Keywords: COVID-19, SARS-CoV-2, antibodies, multiplex, IgG, IgA, IgM

\section{An erratum on:}

Detailed Multiplex Analysis of SARS-CoV-2 Specific Antibodies in COVID-19 Disease Brynjolfsson SF, Sigurgrimsdottir H, Einarsdottir ED, Bjornsdottir GA, Armannsdottir B, Baldvinsdottir GE, Bjarnason A, Gudlaugsson O, Gudmundsson S, Sigurdardottir ST, Love A, Kristinsson KG and Ludviksson BR (2021). Front. Immunol. 12:695230. doi: 10.3389/fimmu.2021.695230

Due to a production error, there was a mistake in Figure $\mathbf{1}$ as published. The image was published in grayscale instead of color. The corrected Figure 1 appears below.

The publisher apologizes for this mistake. The original version of this article has been updated.

Copyright (C) 2021 Frontiers Production Office. This is an open-access article distributed under the terms of the Creative Commons Attribution License (CC BY). The use, distribution or reproduction in other forums is permitted, provided the original author(s) and the copyright owner(s) are credited and that the original publication in this journal is cited, in accordance with accepted academic practice. No use, distribution or reproduction is permitted which does not comply with these terms. 

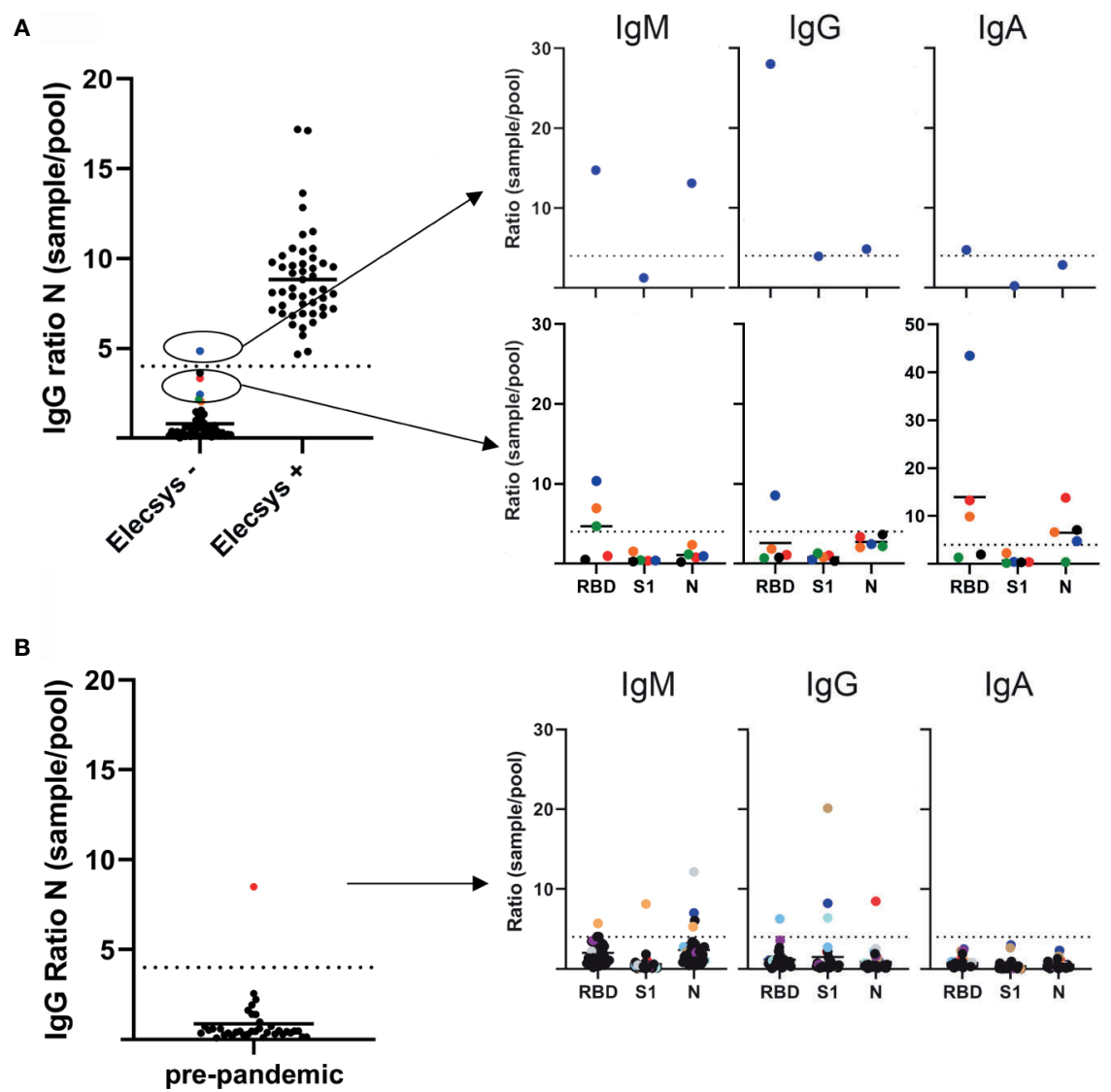

FIGURE 1 | SARS-CoV-2 antibody levels as measured by a multiplex based assay and calibrated against the Elecsys ${ }^{\circledR}$ Anti-SARS-CoV-2 assay (Roche diagnostics). (A) 100 serum samples previously analyzed by Elecsys ${ }^{\circledR}$ assay (depicted on the $x$ axis as negative and positive), were received from the Department of Clinical Microbiology, and SARS-CoV-2 lgG antibodies against the N protein were analyzed blindly by multiplex (left panel). Right top panel depicts the single sample that had a SARS-CoV-2 IgG $>4$ sample/pool ratio for the $\mathrm{N}$ protein. Bottom right panel depicts the samples that showed a $>2$ but $<4$ than 4 sample/pool ratio by multiplex. (B) Left panel depicts 36 serum samples received in 2019 by the Department of Immunology. SARS-CoV-2 IgG antibodies against the $\mathrm{N}$ protein were analyzed by multiplex. Right panel depicts the serum/pool ratio of the serum samples against RBD, S1 and N proteins. Samples above the cut-off level are color coded. 